\title{
FROM AN ESTUARY TO A FRESHWATER LAKE: A PALEO-ESTUARY EVOLUTION IN THE CONTEXT OF HOLOCENE SEA-LEVEL FLUCTUATIONS, SE BRAZIL
}

\author{
Antonio Alvaro Buso Junior ${ }^{1,2} \cdot$ Luiz Carlos Ruiz Pessenda $^{1} \cdot$ Paulo Eduardo de Oliveira ${ }^{3} \bullet$ \\ Paulo César Fonseca Giannini ${ }^{4}$ Marcelo Cancela Lisboa Cohen ${ }^{5}$ Cecília Volkmer-Ribeiro ${ }^{6}$ \\ Sonia Maria Barros de Oliveira ${ }^{4}$ Deborah Ines Teixeira Favaro ${ }^{7} \bullet$ Dilce de Fátima Rossetti ${ }^{8} \bullet$ \\ Flávio Lima Lorente ${ }^{1}$ Marcos Antonio Borotti Filho ${ }^{1}$ Jolimar Antonio Schiavo ${ }^{9}$ \\ José Albertino Bendassolli ${ }^{1}$ Marlon Carlos França ${ }^{10}$ • José Tasso Felix Guimarães ${ }^{10}$ • \\ Geovane Souza Siqueira ${ }^{11}$
}

\begin{abstract}
A sediment core was studied to characterize the influences of Holocene sea-level variations in the Barra Seca River valley, in the Atlantic rainforest, Linhares, Espírito Santo, southeastern Brazil. Biological proxies (pollen, spores, and sponge spicules), ${ }^{14} \mathrm{C}$ dating, granulometry, $\delta^{13} \mathrm{C}, \delta^{15} \mathrm{~N}, \mathrm{C} / \mathrm{N}$ and major chemical elements revealed the establishment and the evolution of a paleo-estuary during the interval from $\sim 7700-585 \mathrm{cal}$ BP. During the interval $\sim 7700-7000 \mathrm{cal} \mathrm{BP}$, the study site was occupied by a bay-head delta, the inner portion of the paleo-estuary, presenting the most dense mangrove coverage of the entire record. In the interval $7000-3200 \mathrm{cal} \mathrm{BP}$, the site was occupied by the central basin, possibly a consequence of the landward migration of the paleo-estuary. This interval presents reduced mangrove coverage, probably due to the permanent flooding of the valley. From $\sim 3200 \mathrm{cal}$ BP, the marine influence at the site decreased probably as result of the seaward migration of the coast line. From $\sim 600 \mathrm{cal} \mathrm{BP}$, the modern floodplain and freshwater lake were established. This interpretation is in agreement with the sea-level curves for the southeastern Brazilian coast, except for the fact that evidence of sea levels lower than the present at $\sim 4000$ and $\sim 2500$ cal BP as suggested by some authors were not found.
\end{abstract}

\section{INTRODUCTION}

During the last glacial period, eustatic sea-level fall induced lowering of the erosion base level and consequently the excavation of river valleys along a land strip presently occupied by the inner shelf and coastal zone. After the Last Glacial Maximum, the eustatic level rose approximately $120 \mathrm{~m}$, culminating in an early Holocene highstand (Murray-Wallace 2007). According to the published relative sea-level (RSL) curves for the southeastern Brazilian coast during the Holocene (Martin et al. 2003; Angulo et al. 2006), the present level was exceeded at $~ 7800-6600 \mathrm{cal}$ BP, reaching a maximum at $\sim 5500$ cal BP, 2-5 $\mathrm{m}$ above the present level (Figure 1), after which, the RSL decreased.

Due to the post-glacial eustatic rise in sea level, many river valleys along continental coasts were drowned, forming estuaries. Under the subsequent RSL fluctuations during the Holocene, these estuaries may have been partially or entirely silted in, and many of them are no longer active. In this study, an interdisciplinary approach allowed the identification of a depositional sequence that represents the evolution of a paleo-estuary during the period $\sim 7700-3200$ cal BP and the establishment of the modern river floodplain and freshwater lake from $\sim 600 \mathrm{cal}$ BP. The evolution of this paleo-

\footnotetext{
${ }^{1}$ Center for Nuclear Energy in Agriculture (CENA/USP), Brazil.

${ }^{2}$ Corresponding author. Email: alvaro.buso.jr@gmail.com.

${ }^{3}$ São Francisco University, Brazil.

${ }^{4}$ Instituto de Geociências da Universidade de São Paulo, Brazil.

${ }^{5}$ Federal University of Pará, Brazil.

${ }^{6}$ Fundação Zoobotânica do Rio Grande do Sul, Brazil.

${ }^{7}$ Instituto de Pesquisas Energéticas e Nucleares, Brazil.

${ }^{8}$ National Institute of Space Research, Brazil.

${ }^{9}$ Universidade Estadual de Mato Grosso do Sul, Brazil.

${ }^{10}$ Programa de Pós-Graduação em Geologia e Geoquímica, Instituto de Geociências, Univ. Federal do Pará (UFPA), Brazil.

${ }^{11}$ Vale Nature Reserve; Brazil.
} 


\section{A A Buso Junior et al.}

estuary seems to be linked to the post-glacial eustatic sea-level rise and to RSL fluctuations during the Holocene along the southeastern Brazilian coast.

\section{STUDY SITE}

Lagoa do Macuco $\left(19^{\circ} 02.584^{\prime} \mathrm{S}, 39^{\circ} 56.695^{\prime} \mathrm{W}\right)$ is a freshwater lake located inside an incised valley of the lower course of the Barra Seca River (Figure 1), $23 \mathrm{~km}$ from the modern shoreline. The valley is within the Barreiras Formation (Neogene), which forms a flat terrace dipping gently to the southeast. The eastern border of this terrace stands alongside a Quaternary coastal plain, which has narrow residual Pleistocene and wide Holocene prograded sand coastal barriers (Dominguez 2009).

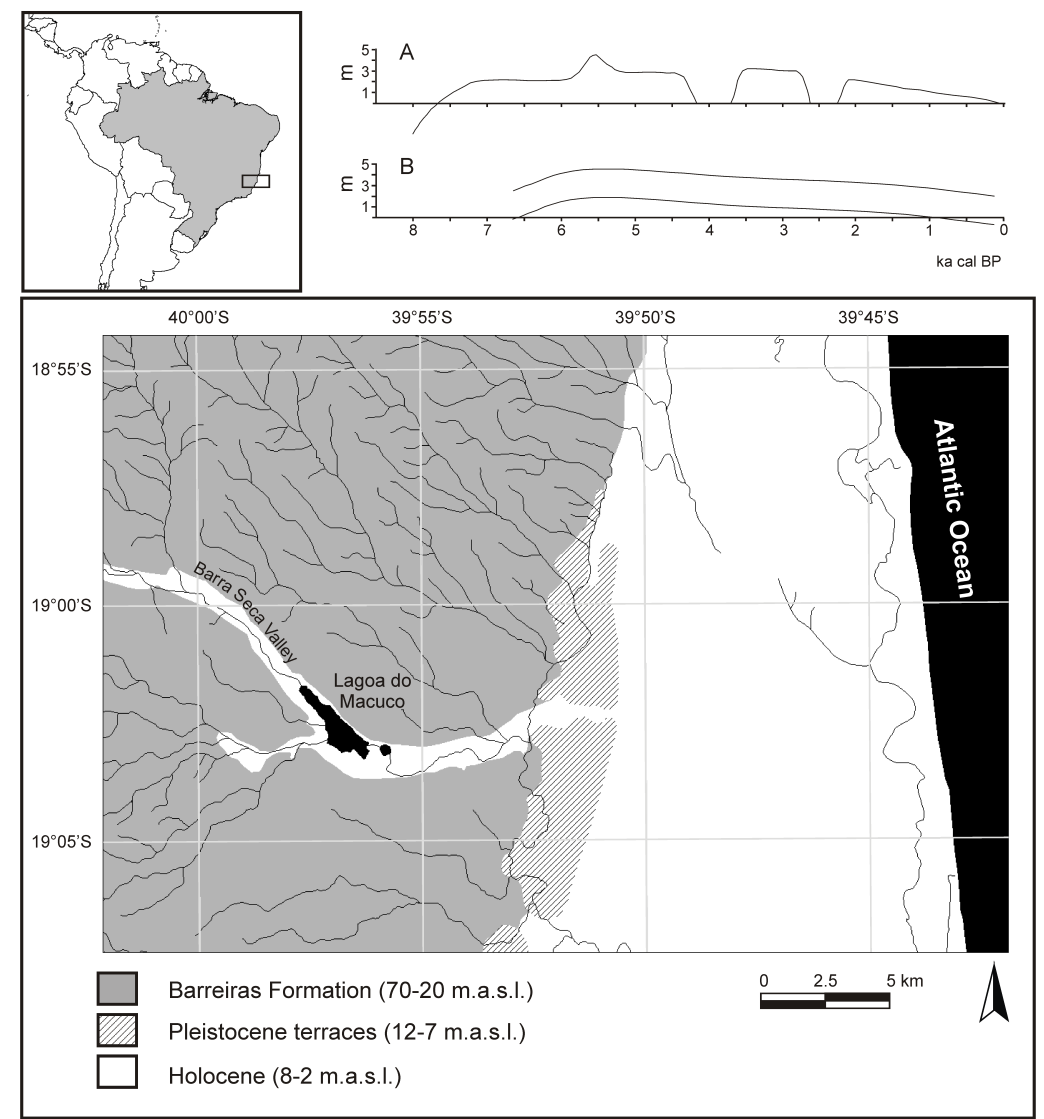

Figure 1 Map showing the location of the study site on the Brazilian coast (upper left panel), and in the geologic and elevation contexts (lower panel); relative sea-level curves for the southeastern Brazilian coast (upper right panel), in meters above present sea level ( $\mathrm{m}$ asl), versus the time in thousands of calibrated years (ka cal BP); (A) subpanel from Martin et al. (2003); (B) subpanel from Angulo et al. (2006).

Vegetation around Lagoa do Macuco is mainly tropical rainforest. Aquatic and littoral vegetation include land plants and emergent, submerged, floating-leaved, and floating plants. A freshwater marsh of herbaceous vegetation occupies the floodplain of the Barra Seca River valley. At the time of sediment coring, the maximum water depth at Lagoa do Macuco was $\sim 3 \mathrm{~m}$, and the altitude at the water surface was $1 \mathrm{~m}$ above sea level (asl). 
From an Estuary to a Freshwater Lake

\section{METHODS}

A 204-cm sediment core (MAC-C) was collected with a modified Livingston piston sediment sampler from a floating platform (Colinvaux et al. 1999) anchored at the center of the lake. At the ${ }^{14} \mathrm{C}$ Laboratory of CENA, samples were collected at 2-cm intervals. ${ }^{14} \mathrm{C}$ dates were obtained from 16 samples, 15 of which were bulk sediment organic matter, and 1 was terrestrial plant fragments (probably bark fragments). These samples were pretreated with $2 \%$ or $4 \%$ hydrochloric acid solution at $60^{\circ} \mathrm{C}$ for $4 \mathrm{hr}$ for carbonate removal, washed, and dried at $50^{\circ} \mathrm{C}$ (Pessenda et al. 2010). After combustion, the purified $\mathrm{CO}_{2}$ was sent to the Isotrace Laboratory, University of Toronto, Canada, or to the University of Georgia, USA, for accelerator mass spectrometry (AMS) dating. The ages are expressed as years before present (BP) and calibrated ages (cal BP, $2 \sigma$ ), according to the SHCal04 calibration curve (McCormac et al. 2004), obtained using CALIB v 6.11 software (http:// calib.qub.ac.uk/calib/). For post-bomb formed samples, we provide the ${ }^{14} \mathrm{C}$ activity as the percentage of modern carbon (pMC), and the calibrated age in cal AD, according to the CALIBomb software (http://calib.qub.ac.uk/CALIBomb/frameset.html). Calibrated ages were used for the construction of a chronology in the Tilia software $\mathrm{v}$ 1.7.16 (Grimm 1992), using a cubic B-spline approximation model, in order to interpolate ages at any undated interval.

For pollen analysis, 26 samples of $1 \mathrm{~cm}^{3}$ were processed according to Colinvaux et al. (1999), with the addition of exotic Lycopodium spores to determine pollen and spores influx (grains $\mathrm{cm}^{-2} \mathrm{yr}^{-1}$ ) as per Davis and Deevey (1964). For each sample, at least 300 arboreal pollen grains were counted. The total pollen sum includes all pollen types and is the basis for calculation of percentages. Pteridophyte spores are not included in the total pollen sum. Identification was based on the pollen reference collection of the ${ }^{14} \mathrm{C}$ Laboratory, CENA/USP. Identified types were grouped into mangrove trees, other trees/shrubs, aquatics, herbs, and terrestrial ferns. Indeterminate pollen includes unidentified and reworked grains.

Analysis of siliceous sponge spicules was carried out on 25 samples, which were processed with hydrogen peroxide $30 \%$ at $60{ }^{\circ} \mathrm{C}$ and hydrochloric acid $10 \%$ at $50{ }^{\circ} \mathrm{C}$. For each sample, a minimum of 250 entire spicules were counted. Classification of spicules from marine sponges was based on Hooper and van Soest (2002). Identification of continental sponge spicules (gemmoscleres and microscleres) was based on Volkmer-Ribeiro and Machado (2007), Tavares et al. (2003), and Volkmer-Ribeiro et al. (2006). Spicules with no particular characteristics (megascleres), which make up the bulk of marine/continental sponge skeletons, whether smooth or spiny, were counted separately aiming to estimate the sponge abundance in the samples. Percentages were based on the total spicules assemblage. For particle-size determination, 71 samples were treated with hydrogen peroxide $(10 \%)$ to remove organic matter and ultrasonically dispersed before analysis by laser diffraction in a Laser Particle Size Shimadzu Sald 3101. The results of grain-size distribution are presented according to the Wentworth (1922) scale.

Elemental and isotopic analyses of total organic carbon and nitrogen were carried out at 2-cm intervals. Contaminant roots were physically removed, and bulk sediment samples were dried at $50{ }^{\circ} \mathrm{C}$. Modern aquatic and semi-aquatic plants from Lagoa do Macuco were also analyzed. Whole plants were washed in deionized water, dried at $40^{\circ} \mathrm{C}$, and grinded. Analyzes were carried out at the Stable Isotope Laboratory (CENA, Piracicaba, Brazil) using an elemental analyzer attached to an ANCA SL 2020 mass spectrometer. Total organic C (TOC) and N are expressed as percentage of dry weight, with analytical precision of $0.09 \%$ and $0.07 \%$, respectively. Isotopic compositions $\left(\delta^{13} \mathrm{C}\right.$ and $\delta^{15} \mathrm{~N}$ ) are measured with respect to VPDB and atmospheric nitrogen, respectively, and are expressed as per mil (\%) with a standard deviation of $\pm 0.2 \%$ (Pessenda et al. 2010). 


\section{A A Buso Junior et al.}

Chemical determination of major elements ( $\mathrm{Si}, \mathrm{Al}, \mathrm{Fe}, \mathrm{Mn}, \mathrm{Mg}, \mathrm{Ca}, \mathrm{Na}, \mathrm{K}, \mathrm{Ti}$, and $\mathrm{P}$ ) was conducted on 25 samples by conventional wavelength-dispersive X-ray fluorescence spectrometry (XRF), using a Philips PW2400 instrument on glass fusion beads. Results are expressed as percent dry weight. Loss on ignition (LOI) was obtained by calcination of dry samples at $1000{ }^{\circ} \mathrm{C}$ for $60 \mathrm{~min}$. Analyses of standard reference material showed accuracy and precision to be better than $5 \%$ RSD for chemical determinations.

\section{RESULTS}

\section{${ }^{14} \mathrm{C}$ Ages, Age-Depth Curves, and Deposition Times}

The accelerator mass spectrometry (AMS) ${ }^{14} \mathrm{C}$ dates range from 7667-7430 cal BP near the base of the core to cal AD 1958-1996 at the top (Table 1). There are some reasons for these dates being considered reliable: (i) the date obtained at $198-200 \mathrm{~cm}$ is from terrestrial plant fragments; (ii) all samples were pretreated for carbonate removal; (iii) marine reservoir effect is probably much reduced due to the mainly continental origin of the organic matter (indicated by $\delta^{13} \mathrm{C}$ and $\mathrm{C} / \mathrm{N}$ ); (iv) lake reservoir effect, hardwater effect, or the assimilation of some other form of old carbon are probably negligible, considering the modern age obtained from sample 4-6 cm, which is the expected age for this depth; (v) the dates are all in stratigraphic order and no irregularities are apparent.

Table $1{ }^{14} \mathrm{C}$ results of the core MAC-C from Lagoa do Macuco.

\begin{tabular}{|c|c|c|c|c|}
\hline $\mathrm{Lab}^{\mathrm{a}} \#$ & Dated material & $\begin{array}{l}\text { Depth } \\
\text { (cm) }\end{array}$ & Age (BP) & $\begin{array}{l}\text { Age } \\
\text { (cal BP; } 2 \sigma)\end{array}$ \\
\hline UGAMS3405 & Bulk sediment & $4-6$ & $101.39 \pm 0.33^{b}$ & $1958-1996^{\mathrm{c}}$ \\
\hline UGAMS3406 & Bulk sediment & $20-22$ & $100 \pm 30$ & 253-0 \\
\hline UGAMS3407 & Bulk sediment & $48-50$ & $110 \pm 30$ & $253-0$ \\
\hline UGAMS4265 & Bulk sediment & $64-66$ & $290 \pm 25$ & $440-154$ \\
\hline TO13702 & Bulk sediment & $68-70$ & $1090 \pm 90$ & $1171-767$ \\
\hline UGAMS3408 & Bulk sediment & $72-74$ & $1430 \pm 30$ & $1348-1190$ \\
\hline TO13483 & Bulk sediment & $76-78$ & $2440 \pm 70$ & $2717-2208$ \\
\hline UGAMS4266 & Bulk sediment & $80-82$ & $3260 \pm 25$ & $3479-3361$ \\
\hline UGAMS4267 & Bulk sediment & $92-94$ & $3820 \pm 25$ & $4238-3992$ \\
\hline TO13699 & Bulk sediment & $108-110$ & $4560 \pm 60$ & $5431-4888$ \\
\hline TO13700 & Bulk sediment & $122-124$ & $4580 \pm 120$ & $5571-4858$ \\
\hline UGAMS4268 & Bulk sediment & $126-128$ & $5460 \pm 30$ & $6293-6024$ \\
\hline UGAMS4269 & Bulk sediment & $134-136$ & $5780 \pm 30$ & $6634-6414$ \\
\hline TO13484 & Bulk sediment & $138-140$ & $6100 \pm 80$ & $7159-6694$ \\
\hline TO13701 & Bulk sediment & $170-172$ & $6470 \pm 70$ & $7458-7172$ \\
\hline TO13485 & Plant fragments & $198-200$ & $6730 \pm 80$ & $7667-7430$ \\
\hline
\end{tabular}

Deposition times (Figure 2) vary from 261 to $2 \mathrm{yr} \mathrm{cm}^{-1}$. Lower deposition times, and presumably higher sedimentation rates, are observed at the base (older than $7000 \mathrm{cal} \mathrm{BP}$ ) and at the top of the core (last $\sim 500 \mathrm{yr}$ ). 


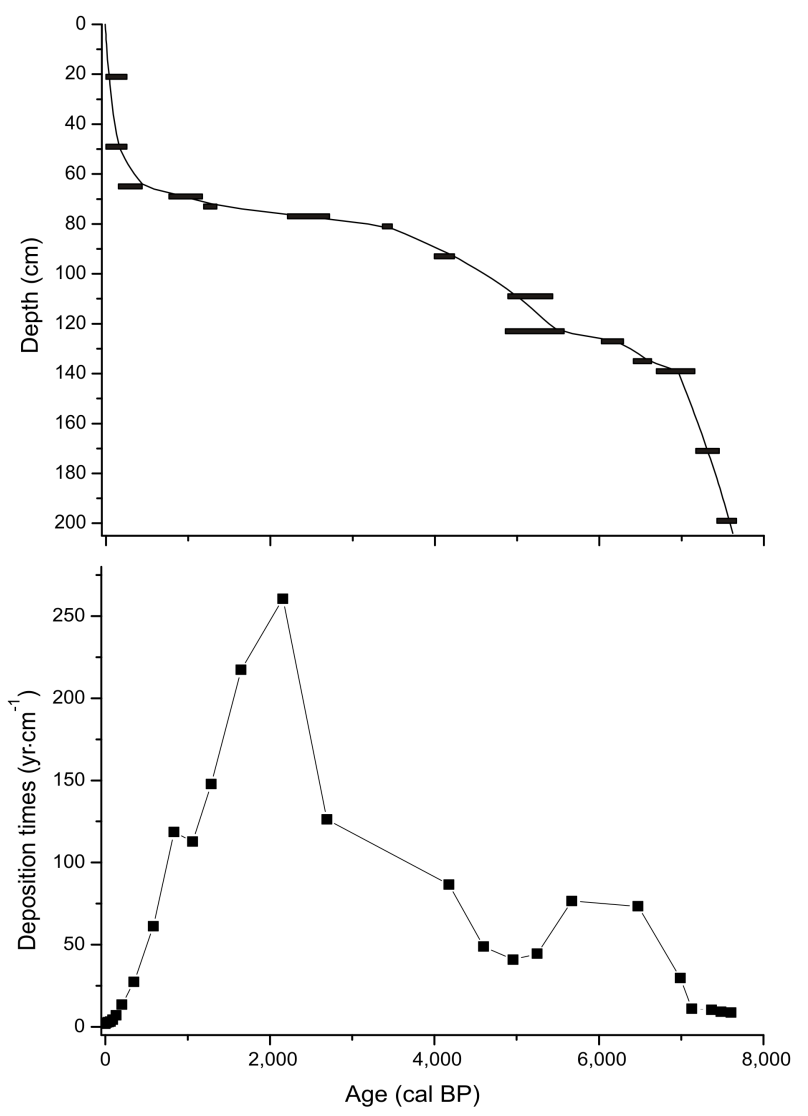

Figure 2 Age-depth curve (upper panel) and deposition times (lower panel) for MAC-C core. In the age-depth curve, horizontal bars indicate calibrated age intervals of the dated samples.

\section{Sediment Macroscopic Characteristics and Granulometry}

The sediment consists of 5 distinct sedimentary intervals (Figure 3A). The bottom layer (204$200 \mathrm{~cm} ; \sim 7667-7589 \mathrm{cal} \mathrm{BP})$ consists of dark green muddy silt. From 200 to $144 \mathrm{~cm}$ (7589-7015 cal BP), the color is dark greenish gray silt and sand with vegetal fragments, with an accumulation of wood fragments near the base $(\sim 198 \mathrm{~cm} ; 7571 \mathrm{cal} \mathrm{BP})$ and wavy laminations consisting of interbedded layers of mud and fine-grained sand. Between 144 and $78 \mathrm{~cm}$ (7015-2692 cal BP), the sediment consists of massive light gray clayey silt. From 78 to $70 \mathrm{~cm}(2692-1059 \mathrm{cal} \mathrm{BP})$, the sediment grades to dark reddish gray silt with transitional contacts. The top $70 \mathrm{~cm}$ (1059 cal BP to present) is a black, soft, peaty gyttja with sand and silt.

\section{Palynology}

Dominant palynomorphs are pollen from mangrove trees, other trees and shrubs, herbs, and aquatic macrophytes, as well spores from terrestrial ferns (Figure 3B, and Table S3 in the online Supplementary information). Lower accumulation rates of total pollen and spores (43-2701 grains cm${ }^{-2}$ $\left.\mathrm{yr}^{-1}\right)$ occur in the interval 202-52 cm (7606-202 cal BP), whereas accumulation rates are higher (6839-39,780 grains $\left.\mathrm{cm}^{-2} \mathrm{yr}^{-1}\right)$ in the interval $44-4 \mathrm{~cm}$ (130 cal BP to present). Percentages of mangrove pollen are higher $(6-53 \%)$ in the interval $202-92 \mathrm{~cm}$ (7606-4176 cal BP). Pollen from other 


\section{A A Buso Junior et al.}

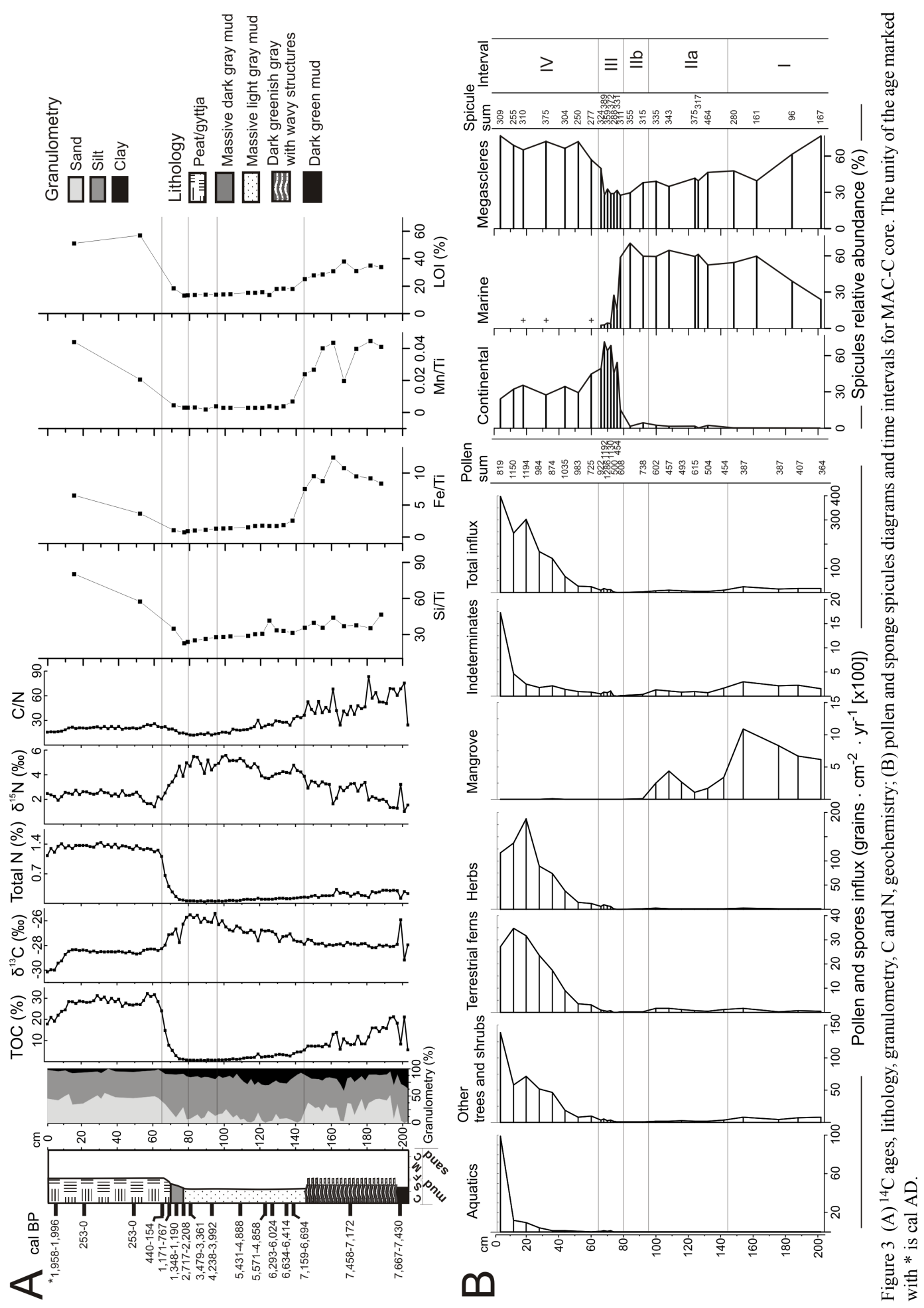


From an Estuary to a Freshwater Lake
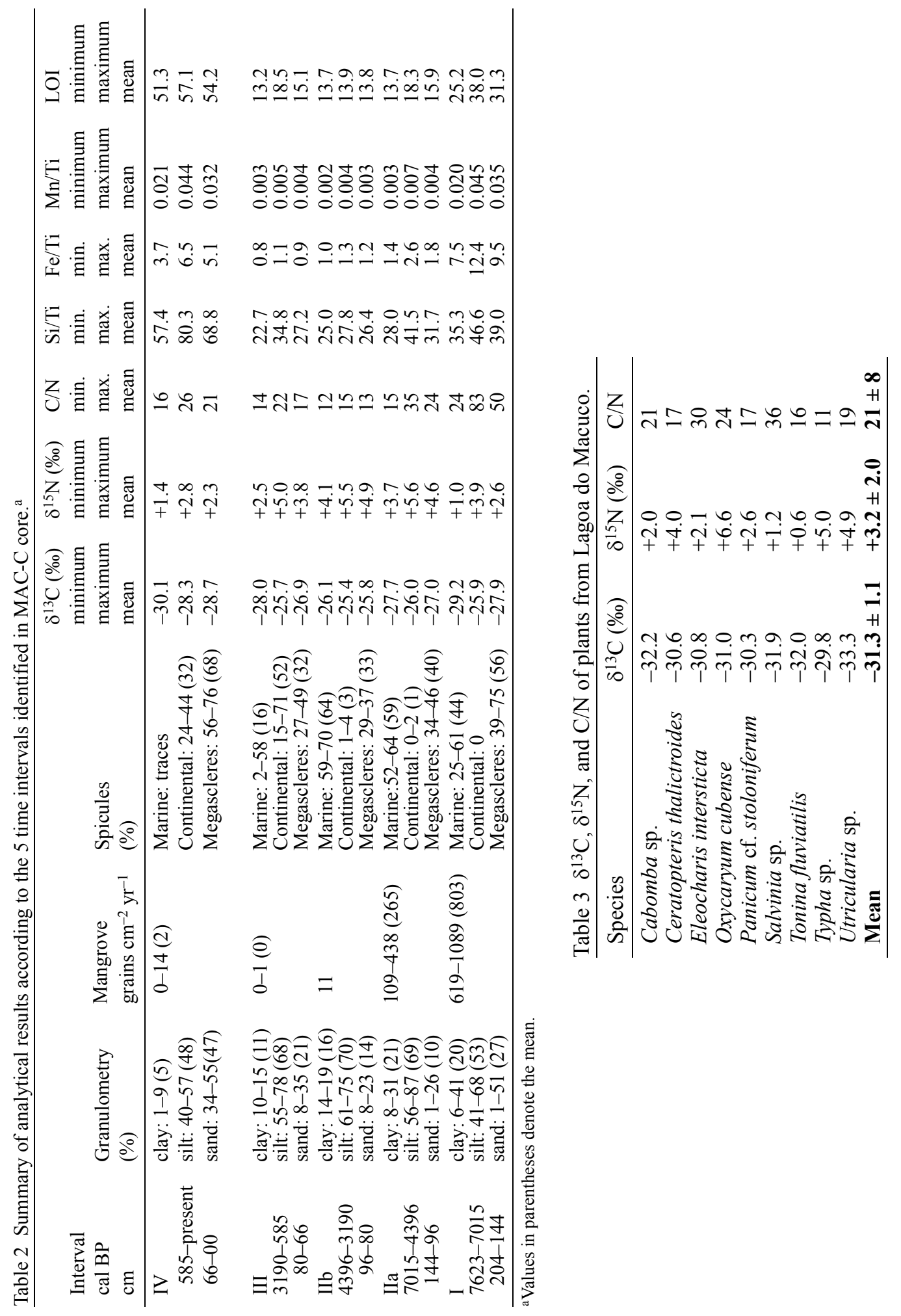


\section{A A Buso Junior et al.}

trees and shrubs are ubiquitous, ranging from $20 \%$ to $70 \%$. Herb pollen percentages are generally low (6-9\%) at the base of the core, 202-154 cm (7606-7131 cal BP), and higher (11-69\%) above $142 \mathrm{~cm}$ (6992 cal BP to the present). The percentages of terrestrial fern spores $=3-23 \%$; pollen from aquatic plants $=0-27 \%$; and indeterminate pollen $=1-19 \%$.

\section{Siliceous Sponge Spicules}

Marine and freshwater spicules point to a net transition from a marine to continental environment around $3000 \mathrm{cal} \mathrm{BP}$. In the interval 204-150 cm $(7623-7085 \mathrm{cal} \mathrm{BP})$, the sum of total spicules is $<250$. Marine spicules varied from $0 \%$ to $70 \%$ (Figure 3B, Table 2), decreasing abruptly above $78 \mathrm{~cm}(\sim 2700 \mathrm{cal} \mathrm{BP})$. Several types of marine sponge spicules are present in the sediment record up to $80 \mathrm{~cm}$. Among the most frequent are acanthotylostyles, oxyasters/spherasters, isochelas, and tylostyles. Spicules from continental sponges ranged from $0 \%$ to $71 \%$, with the most frequent being Racekiela sheilae (Volkmer-Ribeiro et al. 1988), Heteromeyenia cristalina (Batista et al. 2007), Trochospongilla paulula (Bowerbank 1863), Trochospongilla variabilis (Bonetto and Ezcurra de Drago 1973), Ephydatia facunda (Weltner 1895), and Corvomeyenia thumi (Traxler 1895). Megascleres, which may originate from both marine and continental sponges, are also present along the column and their abundance follows that of the presence of marine or continental spicules $(27-76 \%)$.

\section{C and N Analyses}

Organic carbon concentration in the sediment from Lagoa do Macuco varied from $0.5 \%$ to $32.2 \%$ and nitrogen from $0.04 \%$ to $1.4 \%$, resulting in $\mathrm{C} / \mathrm{N}$ ratios of 12 to $83 . \delta^{13} \mathrm{C}$ values ranged from $-30.1 \%$ to $-25.4 \%$ and $\delta^{15} \mathrm{~N}$ from $+1.0 \%$ to $+5.6 \%$ (Figure $3 \mathrm{~A}$, Table 2, and Table S1). In modern semi- and aquatic plants from Lagoa do Macuco, $\delta^{13} \mathrm{C}$ ranged from $-33.3 \%$ to $-29.8 \%$, $\delta^{15} \mathrm{~N}$ from $+0.6 \%$ to $+6.6 \%$, and $\mathrm{C} / \mathrm{N}$ from 11 to 36 (Table 3 ).

\section{Bulk Sediment Geochemistry}

The concentration ranges are as follows: $\mathrm{SiO}_{2}: 27.7-54.0 \% ; \mathrm{Al}_{2} \mathrm{O}_{3}: 12.1-34.3 \% ; \mathrm{Fe}_{2} \mathrm{O}_{3}: 1.7-10.5 \%$; $\mathrm{TiO}_{2}$ : 0.4-2.2\%; $\mathrm{CaO}: 0.04-0.4 \% ; \mathrm{K}_{2} \mathrm{O}: 0.1-0.8 \% ; \mathrm{Na}_{2} \mathrm{O}: 0.05-0.1 \% ; \mathrm{MgO} \%: 0.1-0.5 \% ; \mathrm{MnO}$ : $0.004-0.042 \%$; $\mathrm{P}_{2} \mathrm{O}_{5}: 0.04-0.1 \%$; LOI: $13.2-57.1 \%$ (Table $\mathrm{S} 2$ ). In order to remove the dilution effects and better emphasize the variations of $\mathrm{Si}, \mathrm{Fe}$, and $\mathrm{Mn}$ along the core, concentrations were normalized in relation to $\mathrm{Ti}$, which is a relatively immobile element during weathering (Parker et al. 2006). Si/Ti ratios indicate variation in sand content (Sagemann and Lyons 2003), whereas Fe/Ti and $\mathrm{Mn} / \mathrm{Ti}$ ratios indicate the environmental redox conditions (Boyle 2002). LOI is a proxy for organic matter in carbonate-free sediments (Brauer et al. 2000). In the present study, the depleted values of $\delta^{13} \mathrm{C}$ clearly indicate that the sediment is devoid of carbonates.

\section{DISCUSSION}

\section{Paleo-Estuary Evolution and Modern Environment Formation}

The MAC-C core record has been divided into 5 age intervals (Figure 3, Table 2), 3 of them representing the evolution of a paleo-estuary during a transgression (intervals I, IIa, and IIb; 7623 to 3190 cal BP), one representing the progradation of the paleo-estuary (interval III; 3190-585 cal BP), and the last representing the formation of the modern environment, i.e. the Barra Seca River floodplain and the freshwater lake Lagoa do Macuco (interval IV; 585 cal BP to the present). Identification of the estuarine depositional sequence relies on the distribution of lithofacies, following the facies model presented by Dalrymple et al. (1992). According to this model, the vertical profile of an estuary in a wave-dominated coast ideally shows a transgressive succession, formed during sea-level 
rise, overlain by a progradational estuarine deposit formed during the sea-level highstand. This sequence of estuary evolution is clearly recorded in MAC-C and is presented in detail below.

In interval I (204-144 cm, 7623-7015 cal BP), the presence of wavy laminations and brackish fauna (25-61\% marine sponge spicules) and floral remains are diagnostic of the estuarine sediment. The highest accumulation rates of mangrove pollen (619-1089 grains $\left.\mathrm{cm}^{-2} \mathrm{yr}^{-1}\right)$ suggest that this period had the most dense mangrove cover of the entire record. The values of TOC (5.5-21.2\%), nitrogen $(0.1-0.3 \%)$, and LOI (25.2-38.0\%) indicate high organic matter content derived mainly from vascular $\mathrm{C}_{3}$ plants $\left(\delta^{13} \mathrm{C}-29.2 \%\right.$ to $-25.9 \%$; $\delta^{15} \mathrm{~N}+1.0$ to $+3.9 \%$; $\mathrm{C} / \mathrm{N} 24-83$; see Tables 3 and 4$)$. High Fe/Ti (7.5-12.4) and $\mathrm{Mn} / \mathrm{Ti}(0.020-0.045)$ ratios suggest redox remobilization and reprecipitation of $\mathrm{Mn}$ and $\mathrm{Fe}$. Slides prepared for pollen analysis from this interval showed the presence of black and opaque granules incrustrating vegetal fragments (Figure S1, Supplementary online file). These granules are very similar to pyrite crystals observed by Oenema (1990) and Marnette et al. (1993) in salt marshes and freshwater environments. Pyrite is a reduced form of Fe commonly precipitated in reducing sediments (Megonigal et al. 2003). The integration of characteristics of maximum mangrove density, reducing conditions, and the presence of wavy laminations indicate the dominance of intertidal sedimentation in this interval. This allows interpreting the presence of a bayhead delta, the landward limit of the paleo-estuary.

In intervals IIa and IIb (144-80 cm, 7015-3190 cal BP), the content of mud (clay + silt) is higher than interval I, which the decreasing $\mathrm{Si} / \mathrm{Ti}$ ratios indicate (from a mean value of 39 in interval I to 26 in interval IIb). The higher clay-silt content indicates lower hydrodynamic energy, a characteristic of the estuary central basin (Dalrymple et al. 1992). Lower accumulation rates of mangrove pollen (11-438 grains $\mathrm{cm}^{-2} \mathrm{yr}^{-1}$ ) suggest reduced cover of mangroves, which were probably displaced by transgressive flooding at the core site. Higher percentages of marine sponge spicules $(59-70 \%$ in interval $\mathrm{IIb}$ ) represent more distal deposition of sediments, related to the landward migration of the paleo-estuary. Nonetheless, the presence of well-preserved gemmoscleres of continental sponges from $92 \mathrm{~cm}$ upwards may represent the establishment of freshwater environments close to the study site. Especially in interval $\mathrm{IIb}$, more enriched $\delta^{13} \mathrm{C}(-26.1 \%$ to $-25.4 \%)$ and $\delta^{15} \mathrm{~N}(+4.1 \%$ to $+5.5 \%$ ) and lower $\mathrm{C} / \mathrm{N}(12-15)$ and LOI (13.7-13.9\%), probably indicate higher influx of organic matter from marine phytoplankton and lower influx of organic matter from $\mathrm{C}_{3}$ plants (Tables 3 and 4). Nonetheless, these $\delta^{13} \mathrm{C}$ and $\delta^{15} \mathrm{~N}$ enrichments may also be associated with the oxidation of organic matter in the estuarine zone of maximum turbidity. The estuarine circulation in the zone of maximum turbidity increases the residence time of suspended particulate material (Rossetti 2008), leading to microbial degradation and enrichment of $\delta^{15} \mathrm{~N}$ and $\delta^{13} \mathrm{C}$ in the residual organic matter (Macko and Estep 1984; Owens 1985). During interval IIb, Fe/Ti (1.0-1.3) and Mn/Ti (0.002$0.004)$ ratios show lower values, which could reflect changes in redox conditions.

In interval III (80-66 cm, 3190-585 cal BP), lowered percentages of marine-sponge spicules (58$2 \%$ ) and increased percentages of continental species (15-71\%; see Table 2) suggest that the continental sponges were produced close to, or even at, the study site. An increase in sand sedimentation, indicated by higher Si/Ti ratios (22.7-34.8), reinforces the idea of a more effective fluvial input. These patterns resulted from the progradation of the paleo-estuary. Unlike the previous intervals, only traces of mangrove pollen were found in the sediment, which suggests that mangroves did not colonize the study site. An increase in the total influx of pollen and spores (Figure 3B) suggests increased input of organic matter from vascular plants, especially herbs (26-64\%; Smilax, Poaceae, Cyperaceae, and Sauvagesia) and other trees/shrubs (25-70\%; mainly pioneer taxa such as Symplocos, Ilex, and Melastomataceae/Combretaceae) (Buso Junior et al., these proceedings). In comparison with interval IIb (central basin phase), more depleted $\delta^{13} \mathrm{C}\left(-28.0 \%\right.$ to $-25.7 \%$ ) and $\delta^{15} \mathrm{~N}$ 


\section{A A Buso Junior et al.}

$(+2.5 \%$ to $+5.0 \%)$ and higher $\mathrm{C} / \mathrm{N}$ values (14-22) suggest a tendency for a gradual increase in the contribution of organic matter from vascular $\mathrm{C}_{3}$ plants (Table 4). Nonetheless, a mixture of organic matter from $\mathrm{C}_{3}$ plants, marine, and freshwater phytoplankton, denoted from $\mathrm{C}$ and $\mathrm{N}$ at the beginning of this interval $\left(\delta^{13} \mathrm{C}-26 \% ; \delta^{15} \mathrm{~N}+5 \%\right.$; $\left.\mathrm{C} / \mathrm{N} 14\right)$, may also be considered as a possibility.

Table $4 \delta^{13} \mathrm{C}, \delta^{15} \mathrm{~N}$, and $\mathrm{C} / \mathrm{N}$ of different organic matter sources.

\begin{tabular}{llll}
\hline Organic matter source & $\delta^{13} \mathrm{C}(\%)$ & $\delta^{15} \mathrm{~N}(\%)$ & $\mathrm{C} / \mathrm{N}$ \\
\hline Vascular $\mathrm{C}_{3}$ plants & -33 to -20 & +1 & $\geq 20$ \\
Vascular $\mathrm{C}_{4}$ plants & -17 to -9 & +1 & $\geq 20$ \\
Freshwater phytoplankton & -37 to -25 & +8 & 4 to 10 \\
Marine phytoplankton $^{\mathrm{a}}$ & -21 & +8 & 4 to 10 \\
\hline
\end{tabular}

${ }^{a}$ At southern tropical latitudes. Values according to Rau et al. (1989); Wada et al. (1989); Boutton (1991); Matsuura and Wada (1994); Meyers (2003).

In interval IV (66- $0 \mathrm{~cm}, 585 \mathrm{cal}$ BP to present), pollen assemblages are dominated by herbs (Cyperaceae 25-62\%), trees (Cecropia 4-18\%, Alchornea/Aparisthmium 4-9\%), and aquatic plants (1$27 \%$ ), suggesting the establishment of a plant community similar to the present (Buso Junior et al., these proceedings). Spicules from continental poriferans are dominant (24-44\%), and megascleres are probably derived from continental sponges. Marine sponge spicules are rare or absent. High contents of TOC (17.8-32.2\%) and nitrogen (1.1-1.4\%) and high LOI values (51.3-57.1\%) as well as the values of $\delta^{13} \mathrm{C}$ (mean $-28.7 \%$ ), $\delta^{15} \mathrm{~N}$ (mean $+2.3 \%$ ), and $\mathrm{C} / \mathrm{N}$ (mean 21) are suggestive of the predominance of $\mathrm{C}_{3}$ plants and are quite similar to the values of modern plants (Table 3). These results suggest the establishment of the present environment at the study site, which includes Lagoa do Macuco and the floodplain of the Barra Seca River. The presence of traces of mangrove pollen and marine sponge spicules is probably related to long-distance wind transportation in the case of the pollen grains, and relict material in the case of the spicules. The increasing values of $\mathrm{Si} / \mathrm{Ti}$ ratios (57.4-80.3) are congruent with the elevated fluvial sand supply but may also represent the higher content of biogenic silica originated from sponge spicules and diatoms. The accumulation of organic matter was favored by reducing conditions, leading to more elevated $\mathrm{Fe} / \mathrm{Ti}$ (3.7-6.5) and $\mathrm{Mn} / \mathrm{Ti}$ $(0.021-0.044)$ ratios.

\section{Paleo-Estuary Evolution and Sea-Level Curves for Brazilian Coast}

The age of the base of the core (7623 cal BP) is coeval with the attainment of modern RSL at 7800 $6600 \mathrm{cal} \mathrm{BP}$, according to the sea-level curves for SE Brazil (Figure 1). This age is also in agreement with various sea-level studies summarized by Murray-Wallace (2007), which indicate that modern sea-level was reached around $8000 \mathrm{cal} \mathrm{BP}$. Since the onset of the paleo-estuary would be ideally characterized by the identification of true fluvial deposits underlying the initial flooding surface (Dalrymple et al. 1992), we may conclude that the core did not reach the beginning of the paleoestuary sedimentation, which must have occurred before 7623 cal BP.

The evolution of the paleo-estuary after $7623 \mathrm{cal} \mathrm{BP}$ is in agreement with the general trend of the eustatic sea-level summarized by Murray-Wallace (2007): the sea-level rose worldwide reaching an early Holocene highstand at $\sim 7000$ cal BP. Several coastal regions of the Southern Hemisphere show an early Holocene highstand above the modern sea level followed by a fall in relative sea level to the present height. The high sediment accumulation rates observed at the base of the core (interval I, 7623-7015 cal BP; Figure 2) may indicate the creation of accommodation space due to rising sea level before the early Holocene highstand. This period had the most dense mangrove cover at the site, which was then located at the bay-head delta of the paleo-estuary (Table 2, Figure 3B). 
Following the early Holocene highstand at $\sim 7000$ cal BP, the estuary central basin occupied this section of the Barra Seca valley until the end of interval II ( $\sim 3000 \mathrm{cal}$ BP). In situ filling of the paleoestuary started during the sea-level highstand. Interval III (3190-585 cal BP) represents the paleoestuary progradation, when freshwater conditions prevailed close to the study site. Martin and Suguio (1992) have already suggested the emergence of this sector of the Brazilian coast after $\sim 2500$ cal BP. The last $\sim 600 \mathrm{yr}$ (interval IV) represent the modern environment (floodplain and freshwater lake).

This interpretation is partially in agreement to the relative sea-level curves of southeastern Brazilian coast (Figure 1). The sediment record of Lagoa do Macuco does not show evidence of neither sea level lower than the present at $\sim 4000$ cal BP, nor the high frequencies sea-level oscillations, suggested by Martin et al. (2003).

\section{ACKNOWLEDGMENTS}

The authors would like to thank Vale Nature Reserve (Linhares, Brazil) for the field support, and an anonymous reviewer for important contributions to this paper. This work was funded by Fundação de Amparo à Pesquisa do Estado de São Paulo (FAPESP) grants 2007/03615-5, 2007/06222-4, 2010/18091-4, and 2011/00995-7.

\section{REFERENCES}

Angulo RJ, Lessa GC, De Souza MC. 2006. A critical review of mid- to late-Holocene sea-level fluctuations on the eastern Brazilian coastline. Quaternary Science Reviews 25:486-506.

Batista TCA, Volkmer-Ribeiro C, Melão MGG. 2007. Espongofauna da Área de Proteção Ambiental Meandros do rio Araguaia (GO, MT, TO), Brasil, com descrição de Heteromeyenia cristalina sp. nov. (Porifera, Demospongiae). Revista Brasileira de Zoologia 24(3):60830.

Bonetto AA, Ezcurra de Drago ID. 1973. Aportes al conocimiento de las esponjas del Orinoco. Physis 28(76):211-6.

Boutton TW. 1991. Stable carbon isotope ratios of natural materials. II. Atmospheric, terrestrial, marine and freshwater environments. In: Coleman DC, Fry B, editors. Carbon Isotope Techniques. New York: Academic Press. p 155-71.

Bowerbank JS. 1863. A monograph of the Spongillidae. Proceedings of the Zoological Society of London 1863:440-72.

Boyle JF. 2002. Inorganic geochemical methods in palaeolimnology. In: Last WM, Smol JP, editors. Tracking Environmental Change Using Lake Sediments. Volume 2. Dordrecht: Springer. p 83-141.

Brauer A, Mingram J, Frank U, Günter C, Schettler G, Wulf S, Zolitschka B, Negendank JFW. 2000. Abrupt environmental oscillations during the Early Weichselian recorded at Lago Grade di Monticchio, southern Italy. Quaternary International 73-74:79-90.

Buso Junior AA, Pessenda LCR, De Oliveira PE, Cohen MCL, Giannini PCF, Schiavo JA, Rossetti DF, Volkmer-Ribeiro C, Oliveira SMB, Lorente FL, Borotti Fi- lho MA, Bendassolli JA, França MC, Guimarães JTF, Siqueira GS. 2013. Late Pleistocene and Holocene vegetation, climate dynamics, and Amazonian taxa in the Atlantic Forest, Linhares, SE Brazil. Radiocarbon, these proceedings, doi:10.2458/azu_js_rc.55.16211.

Colinvaux P, De Oliveira PE, Patiño JEM. 1999. Amazon Pollen Manual and Atlas. Manual e Atlas Palinológico da Amazônia. Amsterdam: Harwood Academic Publishers.

Dalrymple WR, Zaitlin BA, Boyd R. 1992. Estuarine facies models: conceptual basis and stratigraphic implications. Journal of Sedimentary Petrology 62(6): $1130-46$.

Davis MB, Deevey Jr ES. 1964. Pollen accumulation rates: estimates from Late-Glacial sediment of Rogers Lake. Science 145(3638):1293-95.

Dominguez JML. 2009. The coastal zone of Brazil. In: Dillenburg SR, Hesp PA, editors. Geology and Geomorphology of Holocene Coastal Barriers of Brazil. Berlin: Springer-Verlag. p 17-46.

Grimm EC. 1992. Tilia and Tilia-graph: pollen spreadsheet and graphics program. Program and Abstracts, 8th International Palynological Congress. Aix-enProvence. p 56.

Hooper JNA, van Soest RWM. 2002. Systema Porifera. $A$ Guide to the Classification of Sponges. Dordrecht: Kluwer Academic. 1756 p.

Macko SA, Estep MLF. 1984. Microbial alteration of stable nitrogen and carbon isotopic compositions or organic matter. Organic Geochemistry 6:787-90.

Marnette ECL, Van Breemen N, Horduk KA, Cappenberg TE. 1993. Pyrite formation in two freshwater systems in the Netherlands. Geochimica et Cosmochim- 


\section{A A Buso Junior et al.}

ica Acta 57:4165-77.

Martin L, Suguio K. 1992. Variation of coastal dynamics during the last 7000 years recorded in beach-ridge plains associated with river mouths: example from the central Brazilian coast. Palaeogeography, Palaeoclimatology, Palaeoecology 99:119-40.

Martin L, Dominguez JML, Bittencourt ACSP. 2003. Fluctuating Holocene sea-levels in eastern and southeastern Brazil: evidence from multiple fossil and geometric indicators. Journal of Coastal Research 19: 101-24.

Matsuura Y, Wada E. 1994. Carbon and nitrogen stable isotope ratios in marine organic matters of the coastal ecosystem in Ubatuba, southern Brazil. Ciência e Cultura 46:141-6.

McCormac FG, Hogg AG, Blackwell PG, Buck CE, Higham TFG, Reimer PJ. 2004. SHCal04 Southern Hemisphere calibration, 0-11.0 cal kyr BP. Radiocarbon 46(3):1087-92.

Megonigal JP, Hines ME, Visscher PT. 2003. Anaerobic metabolism: linkages to trace gases and aerobic processes. In: Holland HD, Turekian KK, editors. Treatise on Geochemistry. Volume 8. San Diego: Elsevier Ltd. p 317-424.

Meyers PA. 2003. Applications of organic geochemistry to paleolimnological reconstructions: a summary of examples from the Laurentian Great Lakes. Organic Geochemistry 34:261-89.

Murray-Wallace CV. 2007. Eustatic sea-level changes since the last glaciation. In: Elias SA, editor. Encyclopedia of Quaternary Science. Amsterdam: Elsevier. p 3034-43.

Oenema O. 1990. Pyrite accumulation in salt marshes in the Eastern Scheldt, southwest Netherlands. Biochemistry 9:75-98.

Owens NJP. 1985. Variations in the natural abundance of ${ }^{15} \mathrm{~N}$ in estuarine suspended particulate matter: a specific indicator of biological processing. Estuarine, Coastal and Shelf Science 20(4):505-10.

Parker AG, Goudie AS, Stokes S, White K, Hodson MJ, Manning M, Kennet D. 2006. A record of Holocene climate change from lake geochemical analyses in southeastern Arabia. Quaternary Research 66(3): 465-76.

Pessenda LCR, Saia SEMG, Gouveia SEM, Ledru MP, Sifeddine A, Amaral PGC, Bendassolli JA. 2010. Last millennium environmental changes and climate inferences in the Southeastern Atlantic forest, Brazil. An- nals of the Brazilian Academy of Sciences 82(3):71729.

Rau GH, Takahashi T, Des Marais DJ. 1989. Latitudinal variations in plankton $\delta^{13} \mathrm{C}$ : implications for $\mathrm{CO}_{2}$ and productivity in past oceans. Nature 341(6242):516-8.

Rossetti DF. 2008. Ambientes estuarinos. In: Silva AJCLP, Aragão MANF, Magalhães AJC, editors. Ambientes de Sedimentação Siliciclástica do Brasil. São Paulo: Beca/BALL edições Ltda. p 194-211.

Sagemann BB, Lyons TW. 2003. Geochemistry of finegrained sediments and sedimentary rocks. In: Holland HD, Turekian KK, editors. Treatise on Geochemistry. Volume 7. San Diego: Elsevier. p 115-58.

Tavares MCM, Volkmer-Ribeiro C, Rosa-Barbosa R. 2003. Primeiro registro de Corvoheteromeyenia australis (Bonetto \& Ezcurra de Drago) para o Brasil, com chave taxonômica para os poríferos do Parque Estadual Delta do Jacuí, Rio Grande do Sul, Brasil. Revista Brasileira de Zoologia 20(2):169-82.

Traxler L. 1895. Spikule vos Süsswasserschwämmen aus Brasilien. Foldtani Kozlony Colônia 25(62-64):23840.

Volkmer-Ribeiro C, Machado VS. 2007. Freshwater sponges (Porifera, Demospongiae) indicators of some coastal habitats in South America: redescriptions and key to identification. Iheringia, Série Zoologia 97(2): 157-67.

Volkmer-Ribeiro C, De Rosa-Barbosa R, Tavares MCM. 1988. Anheteromeyenia sheilae sp. n. e outras esponjas dulciaquícolas da região costeira do Rio Grande do Sul (Porifera, Spongillidae). Iheringia, Série Zoologia 68:83-98.

Volkmer-Ribeiro C, Motta Marques D, Rosa-Barbosa R, Machado VS. 2006. Sponge spicules in sediments indicate evolution of coastal freshwater bodies. Journal of Coastal Research 39:469-72.

Wada E, Kabaya Y, Mitamura O, Saijo Y, Tundisi JG. 1989. Stable isotopic studies on the Rio Doce Valley lake ecosystem in Brazil. In: Saijo Y, Tundisi JG, editors. Limnological Studies in Rio Doce Valley Lakes, Brazil. Nagoya: Nagoya University. p 71-6.

Weltner W. 1895. Spongillidenstudien III. Katalog und Verbreitung der bekannten Süsswasserschswämme. Archiv für Naturgeschichte 61(1):114-44.

Wentworth CK. 1922. A scale of grade and class terms for clastic sediments. The Journal of Geology 30(5): 377-92. 